\title{
A new glacier inventory on southern Baffin Island, Canada, from ASTER data: I. Applied methods, challenges and solutions
}

\author{
Felix SVOBODA, Frank PAUL \\ Department of Geography, University of Zürich-Irchel, Winterthurerstrasse 190, CH-8057 Zürich, Switzerland \\ E-mail: felix.svoboda@gmail.com
}

\begin{abstract}
The quantitative assessment of glacier changes as well as improved modeling of climatechange impacts on glaciers requires digital vector outlines of individual glacier entities. Unfortunately, such a glacier inventory is still lacking in many remote but extensively glacierized regions such as the Canadian Arctic. Multispectral satellite data in combination with digital elevation models (DEMs) are particularly useful for creating detailed glacier inventory data including topographic information for each entity. In this study, we extracted glacier outlines and a DEM using two adjacent Terra ASTER scenes acquired in August 2000 for a remote region on southern Baffin Island, Canada. Additionally, Little Ice Age (LIA) extents were digitized from trimlines and moraines visible on the ASTER scenes, and Landsat MSS and TM scenes from the years 1975 and 1990 were used to assess changes in glacier length and area. Because automated delineation of glaciers is based on a band in the shortwave infrared, we have developed a new semi-automated glacier-mapping approach for the MSS sensor. Wrongly classified debris-covered glaciers, water bodies and attached snowfields were corrected manually for both ASTER and MSS. Glacier drainage divides were manually digitized by combining visual interpretation with DEM information. In this first paper, we describe the applied methods for glacier mapping and the glaciological challenges encountered (e.g. data voids, snow cover, ice caps, tributaries), while the second paper reports the data analyses and the derived changes.
\end{abstract}

\section{INTRODUCTION}

The accelerated wastage of mountain glaciers around the world is the clearest natural signal of ongoing atmospheric warming (e.g. Solomon and others, 2007; Zemp and others, 2008). According to recent climate-change scenarios, the Arctic regions will experience a particularly strong increase in temperature in the coming decades (e.g. ACIA, 2004). Many of the heavily glacierized regions in the Arctic are of icefield or ice-cap type. This implies that their entire area becomes an ablation area once the equilibrium line rises above the glacier. Combined with their often small elevation range, they can thus be considered as extremely sensitive to small temperature changes (Nesje and others, 2008). In consequence, the heavily glacierized Canadian Arctic (e.g. Dyurgerov and Meier, 2005) may strongly contribute to global sea-level rise in the future (e.g. Kaser and others, 2006; Raper and Braithwaite, 2006). In order to quantify presently existing ice resources and model potential future changes more accurately, there is an urgent need for a glacier inventory based on digital vector outlines and digital elevation model (DEM) information (e.g. Meier and others, 2007). The situation is special for the Canadian Arctic, as an inventory has been made based on aerial photography from 1956 to 1959 (National Air Photo Library, Canada, http:// airphotos.nrcan.gc.ca/hist_e.php), but no electronic data have been forwarded to the world data centers (Ommanney, 1980, 2009). However, the paper maps have been archived and were used in some studies (e.g. Dowdeswell and others, 2007). On the other hand, since March 2008, updated maps (including glacier outlines, elevation contour lines, etc.) have been digitally available at no cost from the National Topographic Data Base, Canada (http://www.geogratis.ca). Glacier extent on these digitized maps is generally similar to that of the former inventory, but only contiguous ice masses are shown, some generalization was applied, and glacier perimeters were partly updated. Another source of information is provided by digitally available (scanned) large-scale overview maps which show glacier-covered areas and IDs that have been assigned according to the guidelines by Müller and others (1977).

Since 1984, multispectral satellite data from the Landsat Thematic Mapper (TM) sensor have been available. With a spatial resolution of $\sim 30 \mathrm{~m}$ and a spectral band in the shortwave infrared (SWIR), TM allows the mapping of even small glaciers $\left(<0.1 \mathrm{~km}^{2}\right)$ with automated techniques (e.g. Paul, 2007). This long historic archive of Landsat data also allows the repeated update of glacier inventories at timescales of a few decades as recommended in the strategy of the Global Terrestrial Network for Glaciers (GTN-G) at the tier 5 level (Haeberli, 2006). A previous study on Barnes Ice Cap, Baffin Island, Canada, has also used the TM sensor for glacier mapping and change assessment (Jacobs and others, 1997). In a more recent study by Dowdeswell and others (2007), glacier changes on Bylot Island (north of Baffin Island) from 1958/61 to 2001 were analyzed. They compared the aerial photographs from the original glacier inventory to a Landsat Enhanced TM+ (ETM+) scene and found an ice loss of about 5\%. They also mapped ice-front positions from the Little Ice Age (LIA) maximum extent to derive cumulative length changes.

Several other satellite sensors with similar spatial and spectral characteristics have since been launched and have been used frequently for glacier-mapping purposes (Racoviteanu and others, 2008). Here we use satellite data from the Advanced Spaceborne Thermal Emission and Reflection Radiometer (ASTER) sensor in combination with a DEM derived from the same sensor to map glaciers and ice caps for the southern part of Cumberland Peninsula, Baffin Island, with automated techniques. The DEM is also used to derive 


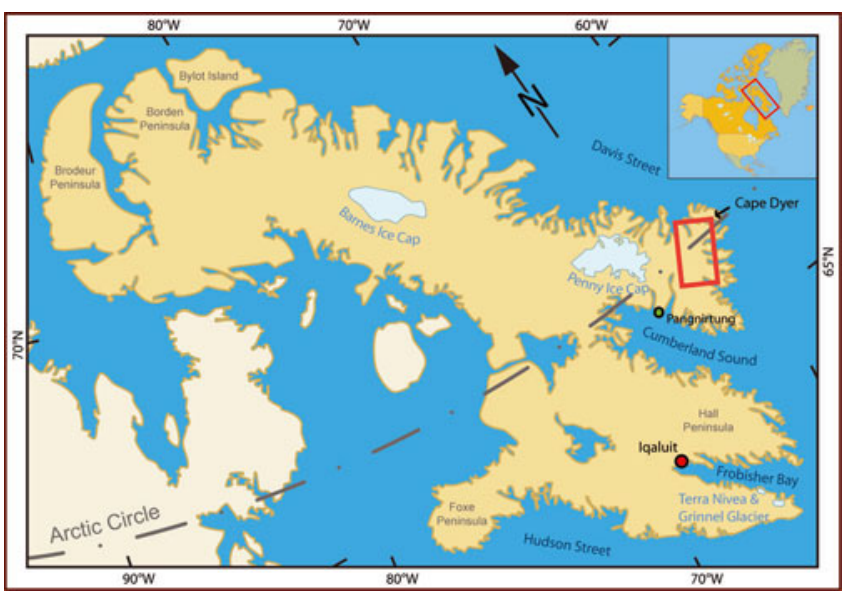

Fig. 1. Location of the study site (red rectangle) on Baffin Island, Canadian Arctic (after http://atlas.gc.ca/).

topographic parameters for each glacier (e.g. minimum, maximum and mean elevation, length, slope, aspect). Additionally, changes in glacier area and length are calculated using a Landsat Multispectral Scanner (MSS) scene from 1975 and manually digitized LIA trimlines and moraines. The TM scene from 1990 had adverse snow conditions and is only used as an additional point in time for length-change calculations.

We have separated this study into two parts: the first part describes in detail the methods and challenges for creating the glacier inventory data from the satellite scenes; the second part (Paul and Svoboda, 2009) presents the results obtained, the data analysis and the change assessment. Special emphasis is given in the second part to the application of the derived parameters to determine glacier volume and volume change since the LIA. The entire study is performed within the framework of the Global Land Ice Measurements from Space (GLIMS) initiative which aims at the compilation of a global glacier inventory from satellite data (e.g. Kargel and others, 2005; Raup and others, 2007).

\section{STUDY SITE AND DATA SOURCES}

\section{Study site}

Around $150000 \mathrm{~km}^{2}$ of the Canadian Arctic is glacierized, which is equivalent to $5 \%$ of the total glacierized area of the Northern Hemisphere (Andrews, 2002). The study site is situated on the southeastern part of Baffin Island, on Cumberland Peninsula, Canada (Fig. 1). Glaciers cover approximately $8 \%\left(36839 \mathrm{~km}^{2}\right)$ of Baffin Island. The two largest ice caps are Barnes Ice Cap $\left(5935 \mathrm{~km}^{2}\right)$ and, adjacent to the study area, Penny Ice Cap $\left(5960 \mathrm{~km}^{2}\right)$ which are believed to be remnants of the Laurentide ice sheet (e.g. Bird, 1967; Ives and others, 1975). The study region is defined by two adjacent ASTER scenes (centered $66.4^{\circ} \mathrm{N}, 62.4^{\circ} \mathrm{W}$, and $66.1^{\circ} \mathrm{N}, 63.2^{\circ} \mathrm{W}$ ) and is crossed by the Arctic Circle. The elevation rises from sea level to $1822 \mathrm{~m}$ a.s.l. The northern part of the study area is rougher, with steep slopes to the sea, while the southern part is hilly. The mean annual air temperature is around $-10^{\circ} \mathrm{C}$ (http://www.knmi.nl), and the precipitation is about $500 \mathrm{~mm}$ w.e. at Cape Dyer (World Meteorological Organization weather station, $393.0 \mathrm{~m}$ a.s.I.), $10 \mathrm{~km}$ to the west of the study area, and declines rapidly towards the west and north (Andrews, 2002).
One-third of the study area is glacierized by individual cirque, mountain, valley, outlet and calving glaciers, as well as highland ice caps. The sizes of the ice masses investigated here range from 0.02 to $296 \mathrm{~km}^{2}$. The low temperature and several push moraines suggest that permafrost is widespread and that glaciers are partly cold (Bennett, 2001). Although glaciers in this region look rather inactive (they show few crevasses and seracs), staggered moraines, proglacial lakes, and moraines/trimlines from the LIA point to a varying history of the glaciers (Paul and Kääb, 2005). The clearly visible LIA moraines and trimlines mark extended glacier forefields which are an explicit sign of the strong retreat of most glaciers during the past century (Wolken, 2006).

\section{Data sources}

The glacier inventory was extracted from two ASTER level 1 B scenes acquired on 13 August 2000 (path 15, row 13/14). Landsat scenes from the MSS and TM sensors were obtained at no cost from the global Geocover dataset (ftp://ftp.glcf. umiacs.umd.edu/glcf/Landsat/) for 27 July 1975 (path 18, row 13) and 19 August 1990 (path 16, row 13), respectively. The Landsat scenes were used to assess changes in glacier parameters (area and length) at a decadal scale. While the MSS scene covers the entire study area, the TM scene covers only two-thirds of it (Fig. 2). Details for the sensors and scenes used in this study are compiled in Table 1. As already outlined in the study by Paul and Kääb (2005), we mapped (LIA) maximum extents from well-preserved trimlines and moraines (Wolken, 2006) using the $15 \mathrm{~m}$ resolution ASTER data.

ASTER has no blue band, and the spatial resolution of the shortwave infrared (SWIR) bands $(30 \mathrm{~m})$ is different from the $15 \mathrm{~m}$ of the visible and near-infrared (VNIR) bands. In this study, the $30 \mathrm{~m}$ SWIR band AST4 was resampled to $15 \mathrm{~m}$ and smoothed with a Gaussian filter in order to reduce its blocky appearance. The major advantage of the ASTER sensor with its along-track stereo bands is the possibility of generating a DEM by stereo correlation of the nadir- and back-looking infrared (IR) band (e.g. Toutin, 2008). Only the TM sensor has a blue band for true-color image composites. The MSS sensor has neither a blue nor a SWIR band and a much coarser spatial resolution $(80 \mathrm{~m})$. MSS is mainly used to determine glacier terminus positions but also for mapping glacier outlines when they are larger than about $0.5 \mathrm{~km}^{2}$. Additionally, digitized maps from the Glacier Atlas of Canada (scale 1:500 000) are freely available from Natural Resources Canada (http://www.atlas.nrcan.gc.ca). They were used to identify potential glaciers and to allocate the former ID codes to the glaciers under consideration.

\section{METHODOLOGY}

In general, the generation of glacier outlines can be divided into three steps: pre-, main and post-processing. The preprocessing step includes data acquisition (download and file import), DEM generation/orthorectification (for ASTER) and the creation of various RGB (red, green, blue) images (for quality control, manual corrections and LIA digitizing). The second step is the glacier mapping itself (band ratio and threshold selection, noise filter application and glacier map export). The final step is the creation of glacier outlines (raster-vector conversion) and application of corrections (e.g. for water, debris, clouds and shadow) as well as glacier basin digitization (hydrologic divides) and DEM 


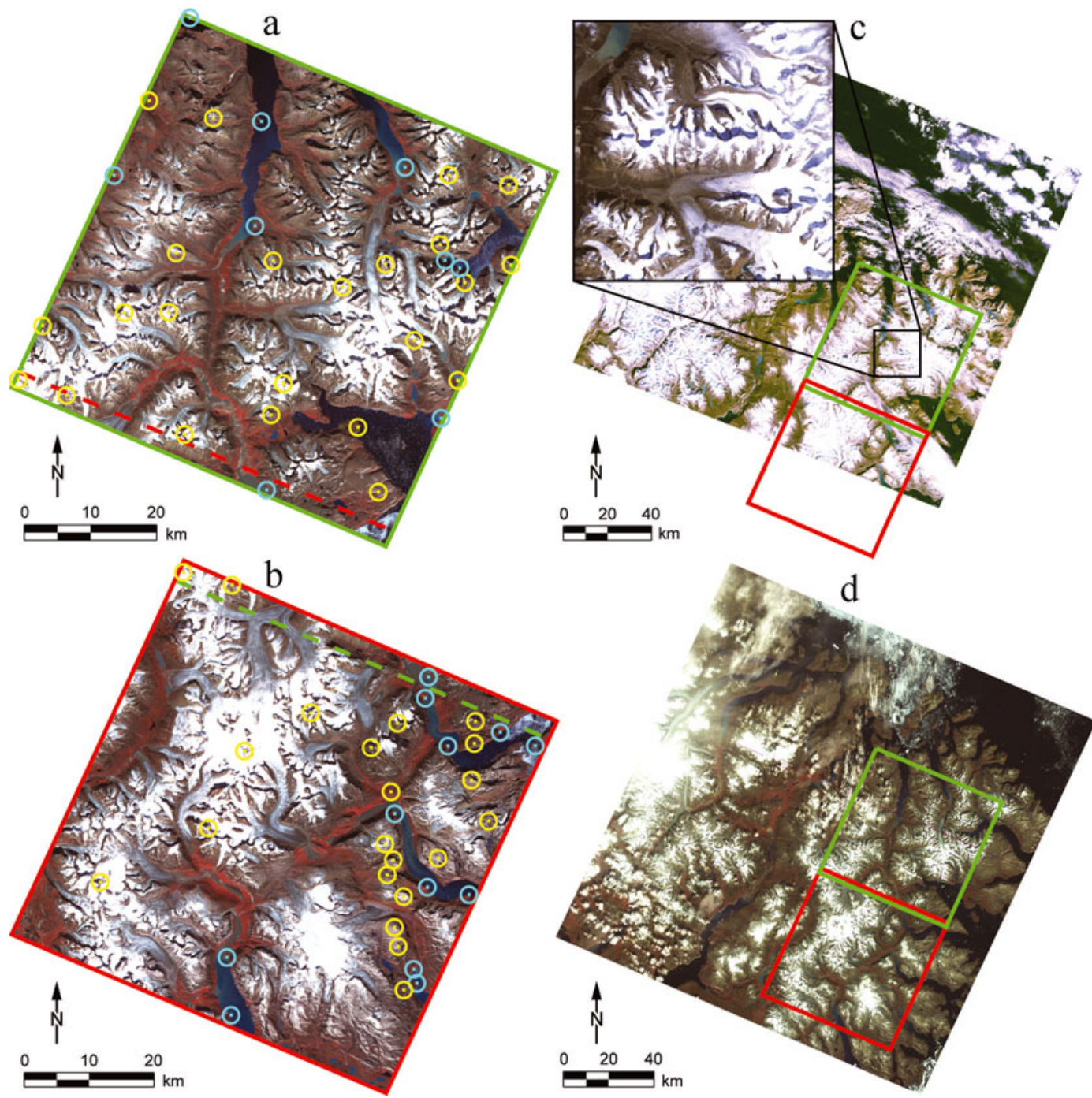

Fig. 2. Overview of the satellite scenes used in this study. (a) Northern and (b) southern ASTER scene, with overlapping parts indicated by a dashed line and used GCPs (circles) at sea level (blue) and above sea level (yellow). (c) TM scene of the study site using bands 3, 2 and 1 as RGB. The southern ASTER scene (red rectangle) is only partly covered. The close-up shows a region with problematic seasonal snow in the TM scene. (d) The MSS scene with bands 3, 2 and 1 as RGB covers both ASTER scenes.

fusion (for calculation of topographic inventory parameters). While the first step depends on the data source (e.g. stereo capability of the sensor) and the software used, the main processing varies with the sensor (e.g. spectral and spatial resolution) and the region (e.g. cloud and snow conditions), and the post-processing depends on the intended application (e.g. creation of a first or updated inventory, analysis of changes, hydrologic calculations, natural hazards). General recommendations for data processing and challenges related to some of the points listed above are also discussed by Racoviteanu and others (2009). In the following, we thus focus on the issues related to the processing in our study region.

\section{DEM generation}

For each ASTER scene, a DEM was obtained from the $3 \mathrm{~N}$ (nadir) and 3B (back-looking) bands at $30 \mathrm{~m}$ cell size (DEM30). In both scenes, 32 ground control points (GCPs) were used. Additionally, 21 and 20 tie points were used for the northern and southern scene, respectively. DEM generation was done with the Orthoengine module of the $\mathrm{PCl}$ Geomatica 9.1 software. The height information was taken from four Canadian topographic maps at scale 1:250 000
$(16 \mathrm{D} / \mathrm{E}, 16 \mathrm{~K} / \mathrm{L}, 26 \mathrm{I}, 26 \mathrm{H})$ and four maps at $1: 50000$ (16E15, $16 \mathrm{~L} 02,16 \mathrm{~L} 08,16 \mathrm{~L} 15)$. The accuracy of the $1: 250000$ and $1: 50000$ maps is given horizontally as 125 and $25 \mathrm{~m}$ and vertically as 100 and $20 \mathrm{~m}$, respectively. We used mountain peaks and points along the coast or at lakes as GCPs. While the GCPs in the northern scene are well distributed over the entire elevation range and scene (Fig. 2a), the GCPs in the southern scene are more concentrated to the eastern shore (Fig. 2b). The overall horizontal root-mean-square error $\left(\mathrm{RMS}_{x, y}\right)$ was 1.87 pixels (northern scene) and 1.18 pixels (southern scene) and the score of the pixel matching for the generated DEM was around $95 \%$. The vertical error $\left(\mathrm{RMS}_{z}\right)$ at the collected GCPs was $90 \mathrm{~m}$ for the northern and $50 \mathrm{~m}$ for the southern scene.

Major problems in the image matching, and thus in DEM generation, are (Fig. 3a and b): (1) atmospheric distortions (clouds, haze); (2) spectral features (low contrast over water, detector saturation over clean snow/ice); (3) illumination (regions in shadow cast by the terrain or clouds); and (4) visibility (on steep north-facing slopes, invisible regions occur for the back-looking telescope). All four points together generate mismatched regions (i.e. data voids) and 'artificial' relief during the correlation process and automatic 
Table 1. Characteristics of the satellites and sensor used (NIR: near infrared; SWIR: shortwave infrared; TIR: thermal infrared; VNIR: visible and near infrared). Values in parentheses (5) indicate the number of summarized bands

\begin{tabular}{|c|c|c|c|c|}
\hline Satellite sensor & Landsat 2 MSS & Landsat $5 \mathrm{TM}$ & \multicolumn{2}{|c|}{ Terra ASTER } \\
\hline \multicolumn{5}{|l|}{ Spectral band } \\
\hline blue & - & $1: 0.45-0.52 \mu \mathrm{m}$ & \multicolumn{2}{|c|}{-} \\
\hline green & $1: 0.5-0.6 \mu \mathrm{m}$ & 2: $0.52-0.60 \mu \mathrm{m}$ & \multicolumn{2}{|c|}{$1: 0.52-0.60 \mu \mathrm{m}$} \\
\hline red & $2: 0.6-0.7 \mu \mathrm{m}$ & 3: $0.63-0.69 \mu \mathrm{m}$ & \multicolumn{2}{|c|}{ 2: $0.63-0.69 \mu \mathrm{m}$} \\
\hline \multirow[t]{2}{*}{ NIR } & $3: 0.7-0.8 \mu \mathrm{m}$ & 4: $0.76-0.90 \mu \mathrm{m}$ & \multicolumn{2}{|c|}{ 3: $0.76-0.86 \mu \mathrm{m}^{*}$} \\
\hline & 4: $0.8-1.1 \mu \mathrm{m}$ & - & \multicolumn{2}{|c|}{-} \\
\hline \multirow[t]{3}{*}{ SWIR } & - & 5: $1.55-1.75 \mu \mathrm{m}$ & \multicolumn{2}{|c|}{ 4: $1.60-1.70 \mu \mathrm{m}$} \\
\hline & - & $6: 2.08-2.35 \mu \mathrm{m}$ & \multicolumn{2}{|c|}{ 5-9: $2.15-2.43 \mu \mathrm{m}(5)$} \\
\hline & - & 7: $10.40-12.50 \mu \mathrm{m}$ & \multicolumn{2}{|c|}{ 10-14: $8.13-11.65 \mu \mathrm{m}(5)$} \\
\hline Spatial resolution & $80 \mathrm{~m}$ & TIR: $120 \mathrm{~m}$, other: $30 \mathrm{~m}$ & \multicolumn{2}{|c|}{ VNIR: $15 \mathrm{~m}$, TIR: $90 \mathrm{~m}$, other: $30 \mathrm{~m}$} \\
\hline Coverage & $\sim 185 \times 185 \mathrm{~km}$ & $\sim 185 \times 185 \mathrm{~km}$ & \multicolumn{2}{|c|}{$\sim 60 \times 60 \mathrm{~km}$} \\
\hline Used scene & & & north & south \\
\hline ID & $021-986$ & $012-287$ & 2008819971 & 2008819974 \\
\hline path/row & 018/013 & 016/013 & 015/013 & 015/014 \\
\hline date & 27 July 1975 & 19 Aug. 1990 & 12 Aug. 2000 & 12 Aug. 2000 \\
\hline source & GLCF & GLCF & GLIMS & GLIMS \\
\hline
\end{tabular}

*Back- and nadir-looking.

parallax-matching method (Kääb, 2002; Toutin and Cheng, 2002). A strong correlation between elevation accuracy and slope has been found by Toutin (2002) which can be summarized as: the steeper the slope, the worse is the elevation accuracy. While low gain settings for the ASTER VNIR bands are a clear advantage for DEM creation over bright surfaces such as glaciers and snow, more data voids have to be expected in regions of shadow due to missing contrast (Toutin, 2008). Moreover, automated glacier mapping in shadow regions with low VNIR gain settings could be error-prone and might even prevent manual correction.

Mismatched regions and artifacts were manually deleted and interpolated with the spatial interpolation tool provided by the software. Larger artifacts were common where pixel

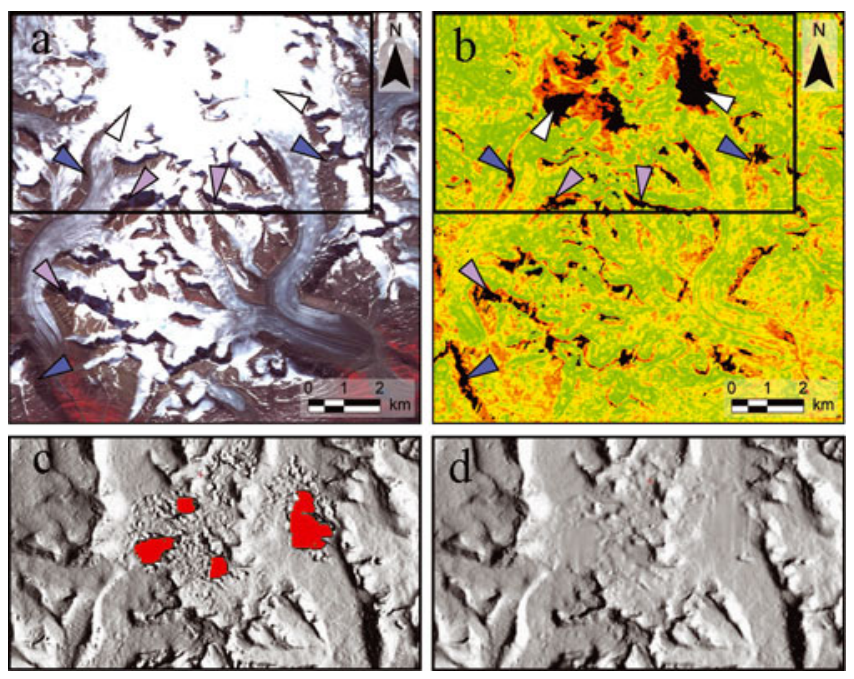

Fig. 3. (a) False-color composite of a subset of the southern ASTER scene and (b) score channel ranging from high (green) over low (red) to no (black) correlation in the pixel-matching process for the same region as shown in (a). Problematic features are indicated by arrows: shadow (violet), steep slopes (blue) and snow (white). (c, d) Hillshade representation of (c) uncorrected (gaps are in red) and $(d)$ corrected DEM. matching was disturbed by steep terrain gradients, low contrast, and oversaturation (Fig. 3). Some pixels at the border of the DEM (around 10 pixels) and around voids in the DEM $(<5$ pixels) were deleted manually because of unrealistic high-elevation values. For the latter, new heights were assigned using the spatial interpolation tool. Small artifacts and noise were reduced with 3 by 3 (kernel size) Gaussian filters (a median filter led to similar results).

As a further height verification, an additionally created DEM with $60 \mathrm{~m}$ cell size (DEM60) was extracted from the ASTER stereo pairs, smoothed with a Gaussian filter, and resampled to $30 \mathrm{~m}$ cell size for better comparability with the DEM30. Indeed, the DEM60 has fewer data voids and artifacts, especially in regions of complex topography (ridges, peaks, steep slopes) and spectrally challenging terrain, such as low-contrast regions (snow and shadow), even though there is less detail. The two DEMs were compared and all cells which differed vertically by $>50 \mathrm{~m}$ were deleted. These cells were assumed to be artifacts. New values were derived for these data voids using the spatial interpolation tools mentioned above. Other studies (e.g. Kääb and others, 2003) used values from the DEM60 as a replacement, but showed that only a weighted DEM fusion results in a smooth transition between both DEMs. This approach was not applied here, as it is a challenging procedure. Orthorectification of the ASTER images was performed with the corrected ASTER DEMs using $\mathrm{PCI}$ Geomatica and the collected GCPs. The MSS and TM scenes were already orthorectified by the Global Land Cover Facility (GLCF) from a different set of GCPs and DEM source. This resulted in a slightly different geolocation than achieved with the ASTER scenes and was manually adjusted in the Geographic Information System with ten additional tie points.

\section{Glacier mapping with ASTER and MSS}

The ideal satellite scene for glacier mapping: (1) is acquired at the end of the ablation period with as little seasonal snow as possible, (2) has a high solar position to avoid deep shadows, (3) includes a SWIR band for automated glacier 


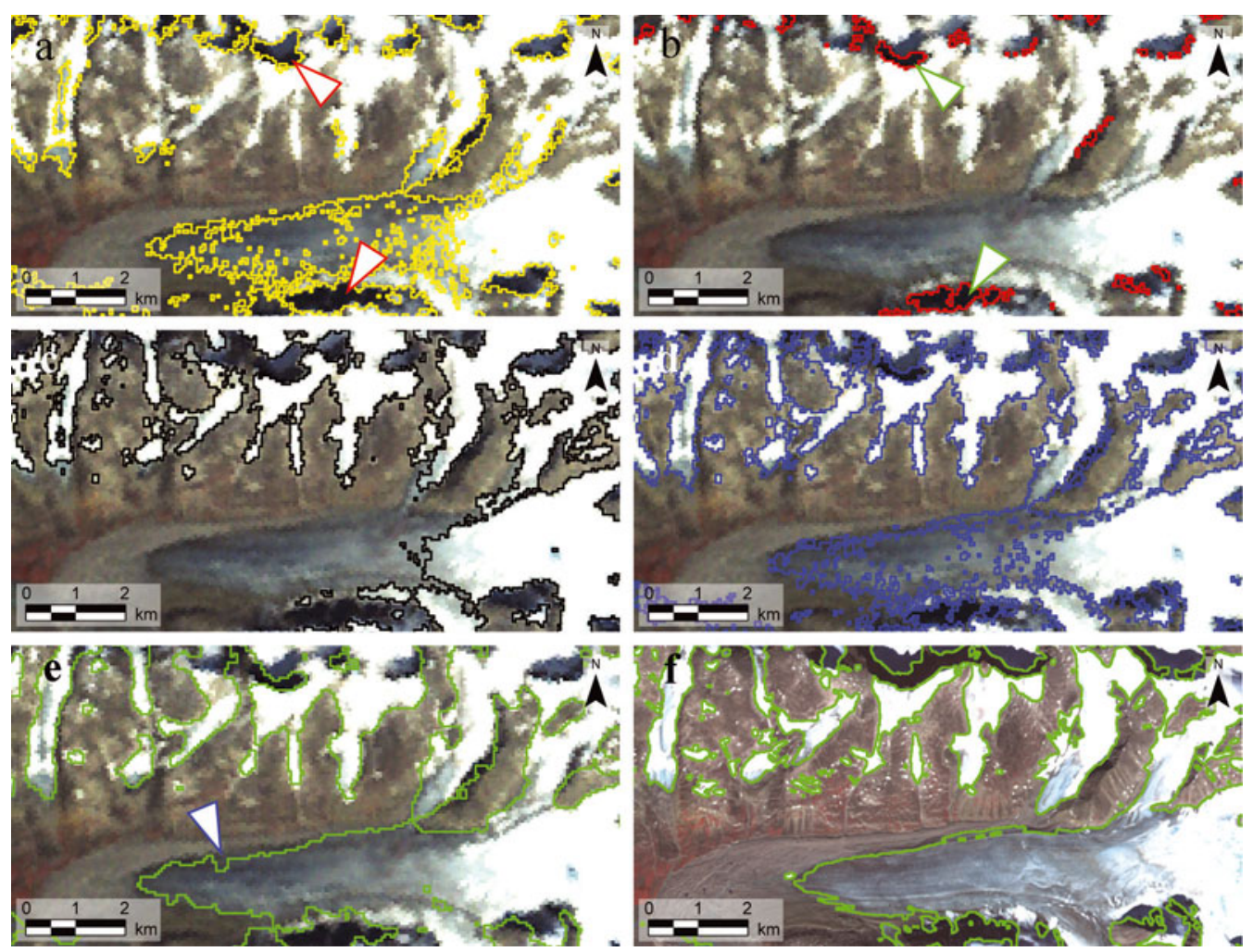

Fig. 4. Illustration of the glacier mapping with the MSS sensor: (a) MSS3/MSS4 $\geq 2$ (red arrows denote misclassified rocks in shadow); (b) MSS3 < 20 (green arrow points to rocks in shadow); (c) MSS 1-3>95; (d) unfiltered glacier map; (e) median filtered glacier map with uncorrected debris cover (blue arrow); and ( $f$ ) for comparison, the median filtered glacier outlines derived from the ASTER scene.

mapping, and (4) is free of clouds. An adequate spatial resolution in respect to the size of the investigated glaciers (e.g. $10-30 \mathrm{~m}$ pixels) is an additional advantage for a high classification accuracy (Paul and Kääb, 2005; Paul, 2007; Raup and others, 2007). Both investigated ASTER scenes are close to such optimal conditions, as only in the southern scene was seasonal snow present, partly hiding the glaciers. The TM scene was partly foggy and there was too much seasonal snow at higher elevations to use it for area change assessment (see close-up in Fig. 2c). At lower elevations, however, snow conditions were acceptable and clearly revealed the glacier terminus. Thus, this scene was used to assess length changes for a subsample of glaciers. Apart from the fact that MSS has no SWIR band and the spatial resolution is much coarser than for TM or ASTER, the snow and atmospheric conditions for glacier detection were adequate (some fog in the eastern part was unproblematic). The MSS scene was thus used for both area- and lengthchange assessment at a decadal scale.

Glacier mapping with ASTER and TM was done using thresholded band ratios (red/SWIR or NIR/SWIR) from the raw digital numbers, which has proved successful in other regions (e.g. Paul and others, 2002; Paul and Kääb, 2005; Raup and others, 2007; Racoviteanu and others, 2008). An additional threshold in the green or blue band was used to distinguish snow/ice in shadow from rock in shadow.

The pronounced spectral differences of ice and snow in the SWIR band (very low reflectance) compared to other surfaces form the base for automated glacier mapping (e.g. Paul, 2002; Bishop and others 2004; Paul and Kääb, 2005). The ratios red/SWIR and NIR/SWIR with an appropriate threshold perform equally well, with slight differences in the shadow (Andreassen and others, 2008). In shadow, the latter could misclassify vegetation and revealed problems at low solar elevations. For this reason, the new European Space Agency (ESA) project GlobGlacier (Paul and others, 2009) uses the red/SWIR ratio with an additional threshold in the green (ASTER) or blue (TM/ETM+) band.

Since there is not much vegetation in the region investigated here, no significant difference between the band ratios is found. The threshold value for the ratio is very robust and is in most scenes investigated so far around $2.0( \pm 0.5)$. In this study, an ASTER scene with low gain settings in the VNIR bands is used, yielding a threshold value of 1.6. Mapping of glaciers in regions of shadow is more sensitive to noise and depends on atmospheric conditions, solar elevation, diffuse reflection from snow cover on adjacent slopes, etc. In this study, the AST1 threshold was set to 47 (AST1 > 47) to exclude rocks in shadow from the glacier classification. The resulting raster glacier map was converted to individual glacier polygons with the attributes 'glacier' or 'no glacier' using the methods described by Paul and others (2002).

For the MSS sensor (see Table 1 for spectral ranges), a decision-tree classifier that utilizes multiple thresholds (Table 2) was used because MSS has no SWIR band (Fig. 4). Instead of a SWIR band, a NIR band was used for the band ratio (MSS3/MSS4). This method proved useful in mapping clean to slightly dirty bare ice and performed well in shadow regions (Fig. 4a). To remove wrongly classified rocks in shadow, an additional threshold in the first NIR band (MSS3) was applied (Fig. 4b). Finally, the first three bands (MSS1-3) were used to map illuminated snow and clean ice (Fig. 4c). The results were satisfying, except in some regions with cast shadow and debris on glaciers (Fig. 4d). Here, the manual correction was more difficult due to the reduced spatial resolution of MSS. 
Table 2. Thresholds used for glacier mapping for all investigated sensors

\begin{tabular}{lcc}
\hline Sensor & Snow and ice* & Snow and ice in shadow \\
\hline ASTER & AST3/AST4 $\geq 1.6$ & AST1 $>47$ \\
TM & TM3/TM5 $\geq 2.0$ & TM1 $>25$ \\
MSS & MSS3/MSS4 $\geq 2.0$ or MSS1-3 $>95$ & MSS3 $>20$ \\
\hline
\end{tabular}

*Partly includes rocks in shadow.

A median filter ( 5 by 5 kernel size) was applied to the corrected glacier map for further noise reduction (Fig. 4e). The filter reduces misclassification due to noise in shadow, removes isolated pixels (snowfields), closes isolated gaps (rock outcrops or small debris/medial moraines), and very small glaciers $\left(<0.1 \mathrm{~km}^{2}\right)$ are decreased in size (Fig. 5; Paul, 2007). Depending on the extent of medial moraines or abundant small snowfields, the kernel size can be varied. In this study, a kernel size of 5 by 5 was chosen, instead of the normally applied 3 by 3 kernel in other studies (e.g. Paul, 2002; Paul and others, 2002). All glacier maps (1975, 1990, 2000) were converted from raster grids into vector polygons for more efficient data handling during post-processing.

Three major problems are encountered in glacier mapping which can be largely solved and are discussed in the following: (1) debris cover, (2) snowfields and (3) water bodies. Ice and snow in cast shadow is mapped accurately when an appropriate additional threshold in the green or blue band is selected (Paul and Kääb, 2005). In order to illustrate the applied corrections, Figure $6 \mathrm{a}$ and b show an example of manually corrected debris cover for the ASTER and MSS sensor, respectively.

1. Thick debris cover on glaciers has the same spectral properties as the debris or the rock walls surrounding the glacier and is thus classified as 'non-glacier'. This is a general problem in automated glacier classification (e.g. Racoviteanu and others, 2009), and semi-automated methods for mapping debris-covered glacier parts have been proposed in several studies (e.g. Bishop and others, 2001; Paul and others, 2004; Bolch and Kamp, 2006; Suzuki and others, 2007). While these methods show promise, a high-quality DEM is needed and visual control and correction of the results is required nevertheless. For this reason, debris-covered parts were delineated manually in this study. This was straightforward with the comparatively high resolution of the ASTER imagery $(15 \mathrm{~m})$, but much more difficult with the coarser MSS resolution $(80 \mathrm{~m})$ as indicated in Figure $6 \mathrm{a}$ and b. In total, corrections for debris cover have been applied to 167 glaciers. They were saved in a separate polygon layer and joined with the raw glacier map. The advantage of the separate debris layer is the possibility for later refinements by subsequent analysis, a separate use for various modeling purposes (e.g. Stokes and others, 2007) and better visualization of the applied corrections.

2. Snowfields are usually 'misclassified' as glaciers because they have the same spectral characteristics as the snow on the glaciers. In this study, glaciers were distinguished from snowfields by the presence of bare ice or based on

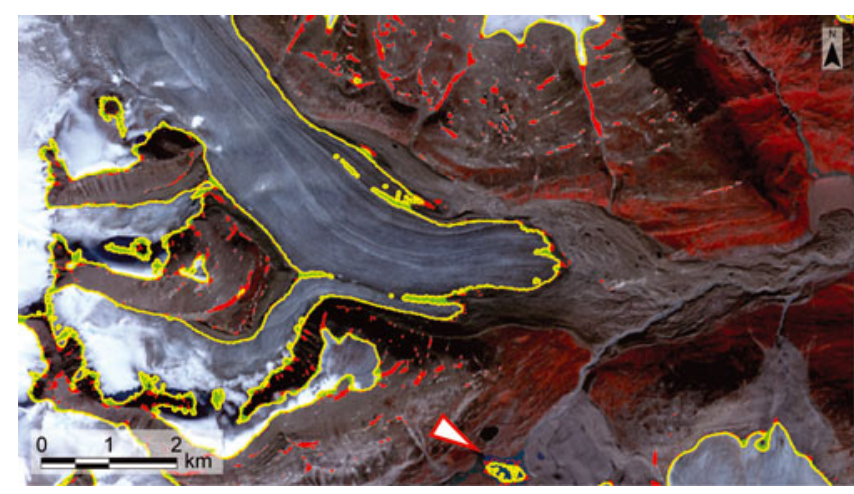

Fig. 5. Influence of the $5 \times 5$ median filter (red: removed, green: added) on the classified glacier outline derived from ASTER (yellow). The red arrow points to a wrongly classified lake.

morphological considerations. Small snowpatches $\left(<0.02 \mathrm{~km}^{2}\right)$ were excluded by applying a size threshold. The method for removing larger snowpatches or those connected to glaciers is discussed below.

3. Most (turbid) water bodies (e.g. ocean, lakes, rivers) are misclassified as glaciers. This is easily corrected, as they are clearly visible in the RGB images created during preprocessing, even if their surface is frozen. The water bodies were directly edited in the vector glacier layer using a false-color composite with the VNIR bands AST 3,2 and 1 (as RGB) in the background.

All clearly visible and identifiable LIA moraines and trimlines were manually delineated for a total of 264 glaciers to derive changes in length and area since the LIA. These were stored as separate polygons, and appended to the year 2000 glacier extent mapped from ASTER scenes. For most glaciers and some ice caps, the delineation is straightforward (Wolken, 2006), but lichen-free zones might also result from persistent snowfields (Koerner, 1980). We tried to exclude such doubtful forefields in this assessment. Further details of the LIA-extent mapping are given by Paul and Kääb (2005).

\section{Glacier basin delineation}

The definition of glacier entities is crucial for the location of drainage divides, calculation of topographic glacier parameters and for change assessment (e.g. Dowdeswell and others, 1995). This definition is especially challenging for complex glacier systems (e.g. compound glaciers, coalescing glaciers, or ice caps with complex topologies) which are often found in the study region. From a glaciological point of view, it has to be considered that the (hydrologic) division of an ice cap into separate units could be questionable. As this strongly depends on the topology or shape of the ice cap, this has to be decided on a case-by-case basis. In this study, glaciers were separated according to their drainage systems as proposed by the UNESCO guidelines (Müller and others, 1977) and the GLIMS data analysis tutorial (B. Raup and S.J. Singh Khalsa, http://www.glims.org/MapsAndDocs/ assets/GLIMS_Analysis_Tutorial_a4.pdf). Contiguous ice masses were split along the topographic divides if flow between the individual parts could be neglected. The DEMs and the aspect grids helped to determine the location of ice divides, but failed in flat parts of joint accumulation areas 

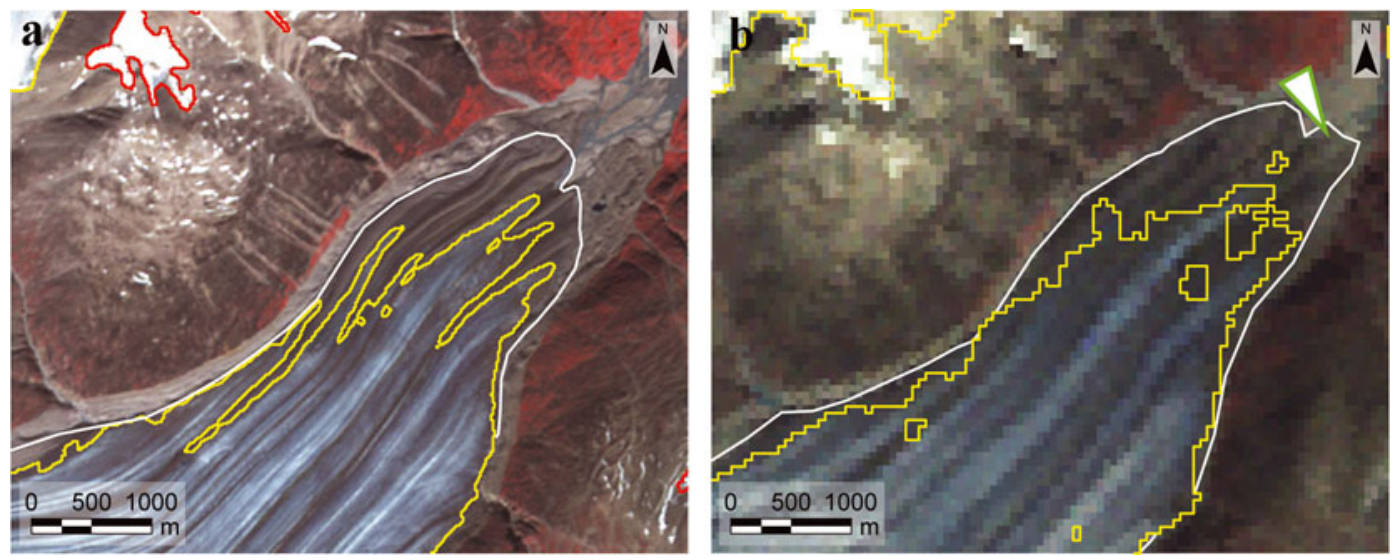

Fig. 6. Comparison of raw glacier outlines (yellow) with debris-cover corrected outlines (white) for (a) the ASTER scene and (b) the MSS scene. The red line in (a) marks a glacier that has been excluded; the green arrow in (b) points to a region where the outline is highly uncertain.

of compound glaciers (Fig. 7a and b). In that case, the location of the divides was estimated based on illumination differences and glaciological interpretation (Racoviteanu and others, 2009). Uncertainty in the location of the divides is indicated by digitizing straight lines as suggested by Paul and Kääb (2005). In cases where small glacier parts were flowing into other drainage systems than the main glacier, they were counted as parts of the larger glacier (Fig. 7a). Glacier basins include all glacier parts that are counted as one entity (year 2000 extent) in the glacier inventory.

In many cases, (seasonal) snowfields or avalanche deposits are found that cross the LIA lateral moraines (in the ablation area) or hide the perimeter of the accumulation area. The glacier basins are also used to separate these snowfields from the main glacier. Due to the overlap, the delineation could be challenging (the basins should be outside the LIA moraines) and introduces some uncertainty in the accumulation area in absolute terms. However, this positional inaccuracy does not influence the area changes calculated here, because all glacier extents (LIA, 1975, $1990,2000)$ refer to the same divides. Perennial snowfields and possible glaciers that are nearly completely snowcovered in the ASTER scene are excluded from the analysis due to the high uncertainties of their true extent (Fig. 6a). However, for submission to the GLIMS glacier database we intend to include them again in a clearly marked form.

All basins were delineated as polygons and identified by glacier IDs which were digitized manually from the maps of the Glacier Atlas of Canada (http://atlas.gc.ca/). Since those glacier IDs were not compliant with the World Glacier Monitoring Service IDs, both IDs were assigned to the respective basins. Because the Glacier Atlas of Canada also contained perennial snowfields, the number of entities in the atlas far exceeds the number of glaciers mapped in this study. Hence, only the IDs from the Glacier Atlas of Canada were taken into account and finally joined with the glacier basins that correspond most closely with the glacier outlines. All glaciers were numbered sequentially according to the World Glacier Inventory numbering system (e.g. Hoelzle and Trindler, 1998). In a final step, the corrected glacier map was intersected by the glacier basins to obtain individual glacier entities (total 662 glaciers) with corresponding glacier IDs.

\section{Flowlines}

The roughness of the DEM and curvature changes downglacier did not allow the automated extraction of flowlines. Thus, hypothetical flowlines were digitized manually to determine total glacier length and length changes. Digitization starts at the lowest point of a glacier and follows a central flowline until the highest point is reached. Ideally, the line crosses the contour lines perpendicularly, and crosses the tongues of all available glacier extents at their furthermost end. The major challenge was thus to identify one central flowline for each glacier and all its tributaries. Although contour lines were used as a visual support, it was not possible to delineate flowlines for all glaciers and ice caps. Finally, the flowlines were intersected with all glacier extents, resulting in the following number of flowline segments: length of the year 2000 (254 lines), length change 1990-2000 (139 lines), length change 1975-2000 (168 lines) and length change LIA-2000 (208 lines).

\section{RESULTS AND DISCUSSION}

After all, two DEMs were extracted from the ASTER scenes, and for each point in time (LIA, 1975, 1990, 2000) one corrected glacier map was derived. The year 1990 glacier map was only used to extract length changes. The digitized LIA extents were appended to the year 2000 extents, so the differences between the two extents are clearly visible (Fig. 8). The further DEM-derived raster grids (aspect, slope, hypsography), the statistical analysis of the derived glacier inventory, and further derived parameters are presented in part II of this study (Paul and Svoboda, 2009).

After the corrections mentioned above have been applied to the ASTER DEM, its quality is sufficient for the purpose of orthorectifying the scenes and deriving glacier parameters. Even though there are many sources of error in the DEM extraction, they do not interfere too much with the results for the topographic glacier parameters. Most of the errors concern: (1) flat parts of glaciers in the snow-covered accumulation area, (2) steep slopes where glaciers are seldom found or (3) sharp ridges/crests. However, the quality of the DEMs was too poor to use them for automated debriscover mapping according to the methods proposed in the studies mentioned above. The automated recognition of basin divides (watershed analysis) performed poorly as well, 

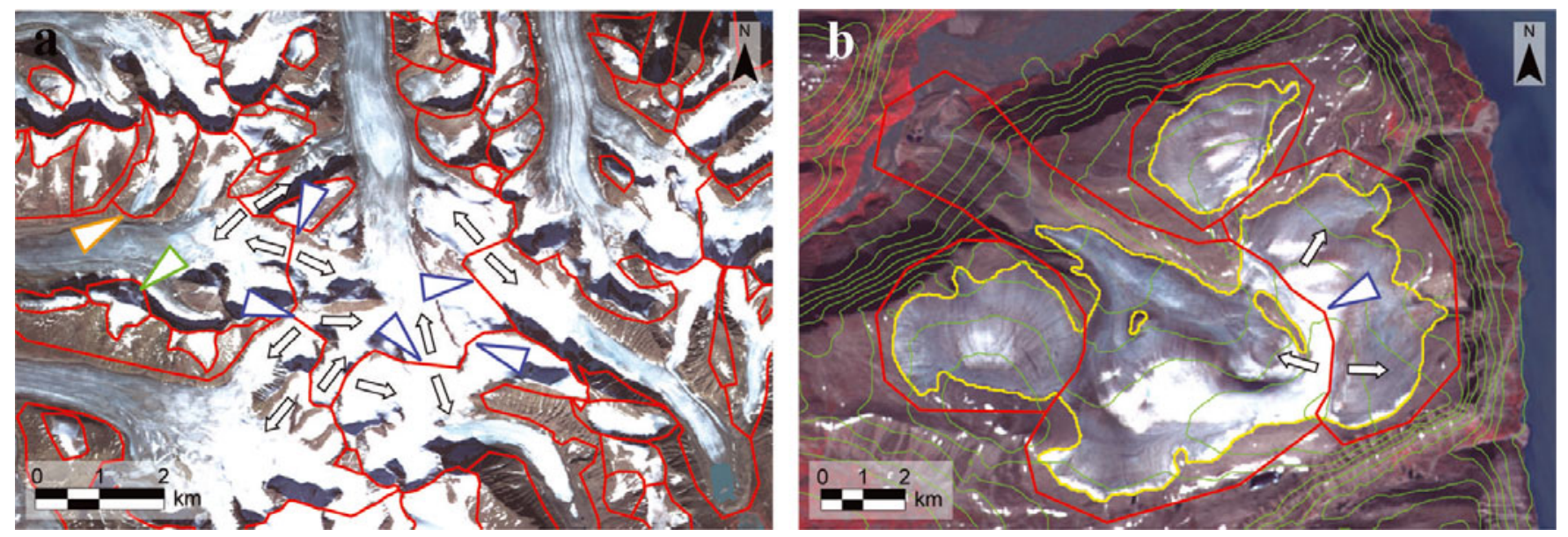

Fig. 7. Glacier basins (red lines) and flow directions (black arrows) for two critical regions. (a) A system of valley glaciers with adjacent accumulation areas. Uncertain divisions are indicated by straight lines (blue arrows); a glacier that contributes mass by ice avalanches (green arrow), and a formerly connected tributary glacier (orange arrow) are also marked. (b) Glacier divides on a mixed ice-cap/valley-glacier system with flow directions into different drainage basins. The critical division along the topographic divide is marked with a blue arrow; glacier outlines are in yellow and $100 \mathrm{~m}$ contour intervals are in green.

but recently developed methods for automated glacier basin delineation (Manley, 2008) have not been tested yet. In the future, high-resolution radar or laser DEMs might help to improve the situation (IGOS, 2007).

The main aim of this study was to create a new glacier inventory for part of Cumberland Peninsula, including mapping of LIA extents and the related assessment of changes in length and area. As the TM scene had too much seasonal snow and only covered two-thirds of the region, it was only used as an additional point in time for lengthchange assessment. Unfortunately, we did not find a better scene in the archives for this region and that period (1990s). Glacier mapping and length-change assessment with MSS is less accurate due to the lack of a SWIR band and the reduced spatial resolution $(80 \mathrm{~m})$. The comparatively low resolution of the MSS sensor made it difficult to identify the glacier terminus and thus to map the debris-covered glacier parts. Similar problems were reported by Hall and others (2003) for a larger debris-covered glacier in Austria (Pasterzenkees). The problem of glacier mapping in shadow regions could be solved by combining the glacier map from MSS with that from ASTER. It is thus assumed that no change has taken place in the upper (shadowed) parts of the accumulation area for those glaciers. To preserve the accuracy of the ASTER-derived glacier map, the LIA extent was appended to the year 2000 extent, instead of the MSSderived 1975 extent.

Due to the missing SWIR channel of MSS, we developed a mapping algorithm that classifies glaciers with multiple thresholds. The mapping was successful except for strongly (i.e. optically thick) debris-covered ice and slightly debriscovered ice in shadow. The manual editing is hampered by the spatial resolution of the sensor $(80 \mathrm{~m})$. However, the semi-automated technique provides glacier outlines for clean ice much faster and more consistently than digitizing by hand. MSS scenes are available for most parts of the world with an archive going back to 1972 . They will be especially interesting for assessment of length and area changes in remote regions with larger glaciers.

Mapping of debris-covered regions is subject to large errors because even in the field it is sometimes difficult to determine whether or not ice exists under the debris. This is particularly the case in regions of shadow and near the terminus when the tongue is flat or collapsing and not well structured (cf. Paul and Kääb, 2005). The accuracy of the delineation also depends on the resolution of the images and the morphology of the glacier (Fig. 6). Therefore, debris cover was delineated in this study by individual polygons before a union with the automatically classified glacier outlines was applied. This also allows automated assignment of different accuracy levels to debris-covered and clean ice.

Even more delicate and complex than debris-cover delineation is the delineation of ice divides in the accumulation region where the quality of the DEM from optical sensors is poor (Fig. 3). In a study on ice caps in the Russian Arctic, Dowdeswell and others (1995) used illumination differences on satellite images with low solar elevations to define principal drainage divides of ice caps. While this method might also work well for the ice caps in the region studied here, the elevation differences in the accumulation regions of connected valley glaciers are likely too small. It is expected that a DEM from radar or laser sensors would help to determine local culminations and flow directions in this region. Such DEMs, which are currently not available for the study site, would also improve the digitizing of flowlines and the quality of extracted glacier parameters, at least when they have been acquired in the same year as the satellite scene. There are some advantages in storing glacier basins as separate polygon datasets: (1) The basins can be reconstructed and edited later, (2) the same basin layer can be applied to different (orthorectified) datasets, (3) they allow selection of specific samples of glaciers, and (4) a common ID can be applied to glacier groups (e.g. including all entities belonging to a former LIA glacier).

The most accurate estimation of glacier retreat is clearly from the mapped LIA position to the year 2000. First, the distances are long, and second the delineation of both extents was based on the high-resolution ASTER image. The terminus positions from 1990 are also precise $( \pm 1$ pixel), even though the length changes to 2000 are mostly small. The error of the 1975-2000 length change is, because of the coarser MSS sensor resolution, about two to three times larger ( \pm 3 pixels) than for the other two sensors (Hall and others, 2003). Also here the glaciological interpretation 
could introduce much higher errors than related to the technical questions discussed above. This particularly applies to the length change since the LIA, as the location of the split from the tributaries could be inaccurate by several hundred meters. Of course, for this study we selected only those glaciers where the situation is clear, but this might be an important point to consider in future studies.

A statistically sound estimate of the mapping accuracy is difficult to calculate for several reasons:

All outlines were already compared and corrected against a ground truth (the used satellite scene). Thus, an independent ground control for error calculation is not available.

Higher-resolution datasets (e.g. aerial photography, IKONOS or QuickBird satellite data) can only be used for comparison when the images have been acquired at the same date (week), which is seldom the case. Moreover, due to the missing SWIR band the delineation is more challenging and details are interpreted differently. Thus, statistical rigor is missing in such comparisons.

On any given image and for clean glaciers, the automatically derived outlines are superior to manually digitized outlines for at least two reasons: the method is consistent with respect to the spectral properties (the same ratio threshold applies to all pixels) and the shape of the outline is not generalized. Both points are important to guarantee reproducible results.

Another relevant issue to consider is that the glaciological uncertainty (e.g. related to the correct position of basin divides, separation from seasonal snowfields, or delineation of debris cover) is much higher than the technical accuracy of the applied glacier-mapping method. As previous comparisons of different methods have shown (e.g. Paul and Kääb, 2005), they could be distinguished only at the level of individual pixels or the workload required for pre- and post-processing (e.g. manual corrections). The 'error' of the mapping method thus has little influence on the accuracy of the final glacier outline.

The estimation of the end of the LIA on Cumberland Peninsula is uncertain. Thompson (1954) showed with lichen analysis that the glaciers were still advancing around 1880 near the study site. Furthermore, several studies estimated that a more pronounced glacier retreat started no earlier than 1920, as a rapid warming was observed after that time (Bird, 1967; Andrews and Barry, 1972; Andrews, 2002). This uncertainty is discussed in more detail in part II of this study (Paul and Svoboda, 2009), where we calculate mean annual mass changes.

\section{CONCLUSIONS}

In this part of the study, we have presented the methods and challenges for mapping glaciers from three optical sensors (ASTER, TM, MSS) in a remote region in the Canadian Arctic (Cumberland Peninsula, Baffin Island). For all sensors, semiautomated mapping methods have been applied, and the datasets required to create a detailed glacier inventory and calculate changes in length and area have been presented. Regarding the now free availability of the entire Landsat archive (US Geological Survey, http://pubs.usgs.gov/fs/ 2008/3091/pdf/fs2008-3091.pdf), we look forward to the

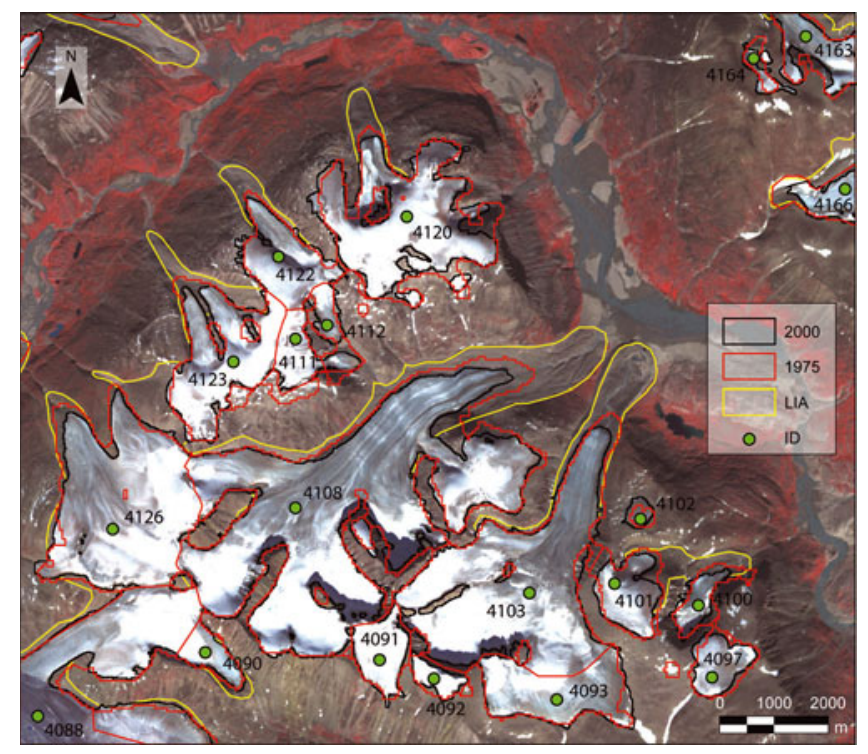

Fig. 8. Example of glacier-mapping results showing the LIA, MSS and ASTER extents (see legend for colors). The ID numbers refer to the Canadian glacier inventory (http://atlas.gc.ca/).

application of the methods presented here in different parts of the world. More specifically, the following conclusions are drawn:

The selection of suitable images from any of the sensors investigated here is challenging in this Arctic region due to adverse weather conditions (frequent clouds, early snow) near the end of the ablation period and the narrow time window with optimal conditions.

ASTER is a very suitable sensor to map even small glaciers at the basin scale. Combined with the possibility to create a DEM from its along-track stereo band, ASTER allows the compilation of data for a detailed glacier inventory (including topographic parameters) in remote regions.

The quality of the DEM is reduced in regions with low contrast (snow, shadow) where data voids occur. These regions can be improved by internal measures (e.g. a $60 \mathrm{~m} \mathrm{DEM}$, interpolation tools).

The Landsat TM (or ETM+) sensor has the advantages over ASTER of covering a region that is nine times larger and having a band in the blue part of the spectrum which facilitates glacier mapping in shadow regions.

Automated glacier mapping with band ratios is a fast, robust, accurate and straightforward method that can be highly recommended for (global) application. It might even be preferable over manual digitization (for debrisfree ice), as it is reproducible, consistent and without generalization.

A semi-automated glacier-mapping method (decisiontree classifier), developed for the MSS sensor, performed well even though the SWIR band is missing. Due to the coarser spatial resolution $(80 \mathrm{~m})$, more intense manual corrections have to be carried out (debris cover, snowfields) and the accuracy of the total area and the derived length changes is reduced. A minimum glacier size of about $0.1 \mathrm{~km}^{2}$ can be mapped. 
Of particular interest for change assessment with MSS is its long historic archive dating back to 1972.

Major challenges to achieve accurate results are related to issues of glaciological interpretation (e.g. location of ice divides, interpretation of debris cover, attached seasonal snow, deep shadows), rather than the technical accuracy of the method used for glacier classification.

Keeping the raw and corrected glacier outlines as well as the basins in separate vector layers allows very efficient and consistent data handling (e.g. regarding later corrections, exclusion of attached snowfields, consideration of former extents, and further applications). Moreover, the separate basin layer could be applied to further (orthorectified) datasets and used to apply joint codes.

The average time required for correcting and preparing one glacier (terminus, debris, flowline, basins) is around $10 \mathrm{~min}$. An additional $5 \mathrm{~min}$ per glacier has to be taken into account to delineate the LIA extents.

\section{ACKNOWLEDGEMENTS}

We thank A. Racoviteanu and an anonymous reviewer for constructive comments, and the scientific editor G. Cogley for careful editing and suggestions. The study was funded by the ESA project GlobGlacier (21088/07/I-EC) and has been performed within the framework of the GLIMS initiative. GLIMS also provided the ASTER imagery used in this study. The TM and MSS scenes were obtained from the GLCF at the University of Maryland, USA.

\section{REFERENCES}

Andreassen, L.M., F. Paul, A. Kääb and J.E. Hausberg. 2008. Landsat-derived glacier inventory for Jotunheimen, Norway, and deduced glacier changes since the 1930s. Cryosphere, 2(2), 131-145.

Andrews, J.T. 2002. Glaciers of the Arctic islands. Glaciers of Baffin Island. In Williams, R.S., Jr and J.G. Ferrigno, eds. Satellite image atlas of glaciers of the world. Denver, CO, United States Geological Survey, K424-K439. (USGS Professional Paper 1386-K.)

Andrews, J.T. and R.G. Barry 1972. Present and paleo-climatic influences on the glacierization and deglacierization of Cumberland Peninsula, Baffin Island, N.W.T., Canada. Boulder, CO, University of Colorado. Institute of Arctic and Alpine Research. (INSTAAR Occasional Paper 2.)

Arctic Climate Impact Assessment (ACIA). 2004. Impacts of a warming Arctic: Arctic Climate Impact Assessment. Cambridge, etc., Cambridge University Press.

Bennett, M.R. 2001. The morphology, structural evolution, and significance of push moraines. Earth Sci. Rev., 53(3-4), 197-236.

Bird, J.B. 1967. The physiography of Arctic Canada, with special reference to the area south of Parry Channel. Baltimore, MD, The Johns Hopkins University Press.

Bishop, M.P., R. Bonk, U. Kamp, Jr and J.F. Shroder, Jr. 2001. Terrain analysis and data modeling for alpine glacier mapping. Polar Geogr., 25(3), 182-201.

Bishop, M.P. and 16 others. 2004. Global land ice measurements from space (GLIMS): remote sensing and GIS investigations of the Earth's cryosphere. Geocarto Int., 19(2), 57-84.

Bolch, T. and U. Kamp. 2006. Glacier mapping in high mountains using DEMs, Landsat and ASTER data. Grazer Schr. Geogr. Raumforsch., 41, 37-48.

Dowdeswell, J.A., A.F. Glazovsky and Yu.Ya. Macheret. 1995. Ice divides and drainage basins on the ice caps of Franz Josef Land,
Russian High Arctic, defined from Landsat, KFA-1000, and ERS-1 SAR satellite imagery. Arct. Alp. Res., 27(3), 264-270.

Dowdeswell, E.K., J.A. Dowdeswell and F. Cawkwell. 2007. On the glaciers of Bylot Island, Nunavut, Arctic Canada. Arct. Antarct. Alp. Res., 39(3), 402-411.

Dyurgerov, M.B. and M.F. Meier. 2005. Glaciers and the changing Earth system: a 2004 snapshot. Boulder, CO, University of Colorado. Institute of Arctic and Alpine Research. (INSTAAR Occasional Paper 58.)

Haeberli, W. 2006. Integrated perception of glacier changes: a challenge of historical dimensions. In Knight, P.G., ed. Glacier science and environmental change. Oxford, Blackwell, 423-430.

Hall, D.K., K.J. Bayr, W. Schöner, R.A. Bindschadler and J.Y.L. Chien. 2003. Consideration of the errors inherent in mapping historical glacier positions in Austria from ground and space (1893-2001). Remote Sens. Environ., 86(4), 566-577.

Hoelzle, M. and M. Trindler. 1998. Data management and application. In Haeberli, W., M. Hoelzle and S. Suter, eds. Into the second century of worldwide glacier monitoring: prospects and strategies. Paris, UNESCO Publishing, 53-72. (Studies and Reports in Hydrology 56.)

Integrated Global Observing Strategy (IGOS). 2007. Cryosphere theme report - For the monitoring of our environment from space and from Earth. Geneva, World Meteorological Organization. (WMO/TD-No. 1405.)

Ives, J.D., J.T. Andrews and R.G. Barry. 1975. Growth and decay of the Laurentide ice sheet and comparison with FennoScandinavia. Naturwiss., 62(3), 118-125.

Jacobs, J.D., É.L. Simms and A. Simms. 1997. Recession of the southern part of Barnes Ice Cap, Baffin Island, Canada, between 1961 and 1993, determined from digital mapping of Landsat TM. J. Glaciol., 43(143), 98-102.

Kääb, A. 2002. Monitoring high-mountain terrain deformation from repeated air- and spaceborne optical data: examples using digital aerial imagery and ASTER data. ISPRS J. Photogramm. Remote Sens., 57(1-2), 39-52.

Kääb, A. and 6 others. 2003. Glacier monitoring from ASTER imagery: accuracy and applications. EARSeL eProc., 2(1), 43-53.

Kargel, J.S. and 16 others. 2005. Multispectral imaging contributions to global land ice measurements from space. Remote Sens. Environ., 99(1-2), 187-219.

Kaser, G., J.G. Cogley, M.B. Dyurgerov, M.F. Meier and A. Ohmura. 2006. Mass balance of glaciers and ice caps: consensus estimates for 1961-2004. Geophys. Res. Lett., 33(19), L19501. (10.1029/2006GL027511.)

Koerner, R.M. 1980. The problem of lichen-free zones in Arctic Canada. Arct. Alp. Res., 12(1), 87-94.

Manley, W.F. 2008. Geospatial inventory and analysis of glaciers: a case study for the eastern Alaska Range. In Williams, R.S., Jr and J.G. Ferrigno, eds. Satellite image atlas of glaciers of the world. Denver, CO, United States Geological Survey, K424-K439. (USGS Professional Paper 1386-K.)

Meier, M.F. and 7 others. 2007. Glaciers dominate eustatic sealevel rise in the 21st century. Science, 317(5841), 1064-1067.

Müller, F., T. Caflisch and G. Müller 1977. Instructions for the compilation and assemblage of data for a world glacier inventory. Zürich, IAHS(ICSI)/UNEP/UNESCO. Temporary Technical Secretariat for the World Glacier Inventory. Swiss Federal Institute of Technology (ETH).

Nesje, A., J. Bakke, S.O. Dahl, Ø. Lie and J.A. Matthews. 2008. Norwegian mountain glaciers in the past, present and future. Global Planet. Change, 60(1-2), 10-27.

Ommanney, C.S.L. 1980. The inventory of Canadian glaciers: procedures, techniques, progress and applications. IAHS Publ. 126 (Workshop at Riederalp 1978 - World Glacier Inventory), $35-44$.

Ommanney, C.S.L. 2009. Canada and the World Glacier Inventory. Ann. Glaciol., 50(53) (see paper in this issue). 
Paul, F. 2002. Changes in glacier area in Tyrol, Austria, between 1969 and 1992 derived from Landsat TM and Austrian glacier inventory data. Int. J. Remote Sens., 23(4), 787-799.

Paul, F. 2007. The new Swiss glacier inventory 2000 - application of remote sensing and GIS. Schriftenreihe Physische Geographie, Univ. Zürich 52.

Paul, F. and A. Kääb. 2005. Perspectives on the production of a glacier inventory from multispectral satellite data in Arctic Canada: Cumberland Peninsula, Baffin Island. Ann. Glaciol., 42, 59-66.

Paul, F. and F. Svoboda. 2009. A new glacier inventory on southern Baffin Island, Canada, from ASTER data: II. Data analysis, glacier change and applications. Ann. Glaciol., 50(53) (see paper in this issue).

Paul, F., A. Kääb, M. Maisch, T. Kellenberger and W. Haeberli. 2002. The new remote-sensing-derived Swiss glacier inventory. I. Methods. Ann. Glaciol., 34, 355-361.

Paul, F., C. Huggel and A. Kääb. 2004. Combining satellite multispectral image data and a digital elevation model for mapping debris-covered glaciers. Remote Sens. Environ., 89(4), 510-518.

Paul, F., A Kääb, H. Rott, A. Shepherd, T. Strozzi and E. Volden. 2009. GlobGlacier: mapping the world's glaciers and ice caps from space. EARSel eProc., 8(1), 11-25.

Racoviteanu, A.E., M.W. Williams and R.G. Barry. 2008. Optical remote sensing of glacier characteristics: a review with focus on the Himalaya. Sensors, 8(5), Special Issue, 3355-3383.

Racoviteanu, A.E., F. Paul, B. Raup, S.J.S. Khalsa and R. Armstrong. 2009. Glacier mapping from satellite data within Global Land Ice Measurements from Space (GLIMS). Ann. Glaciol., 50(53) (see paper in this issue).

Raper, S.C.B. and R.J. Braithwaite. 2006. Low sea level rise projections from mountain glaciers and icecaps under global warming. Nature, 439(7074), 311-313.
Raup, B. and 11 others. 2007. Remote sensing and GIS technology in the Global Land Ice Measurements from Space (GLIMS) Project. Comput. Geosci., 33(1), 104-125.

Solomon, S. and 7 others, eds. 2007. Climate change 2007: the physical science basis. Contribution of Working Group I to the Fourth Assessment Report of the Intergovernmental Panel on Climate Change. Cambridge, etc., Cambridge University Press.

Stokes, C.R., V. Popovnin, A. Aleynikov, S.D. Gurney and M. Shahgedanova. 2007. Recent glacier retreat in the Caucasus Mountains, Russia, and associated increase in supraglacial debris cover and supra-/proglacial lake development. Ann. Glaciol., 46, 195-203.

Suzuki, R., K. Fujita and Y. Ageta. 2007. Spatial distribution of thermal properties on debris-covered glaciers in the Himalayas derived from ASTER data. Bull. Glaciol. Res. 24, 13-22.

Thompson, H.R. 1954. Pangnirtung Pass, Baffin Island: an exploratory regional geomorphology. (PhD thesis, McGill University.)

Toutin, T. 2002. Three-dimensional topographic mapping with ASTER stereo data in rugged topography. IEEE Trans. Geosci. Remote Sens., 40(10), 2241-2247.

Toutin, T. 2008. ASTER DEMs for geomatic and geoscientific applications: a review. Int. J. Remote Sens., 29(7), 1855-1875.

Toutin, T. and P. Cheng. 2002. Comparison of automated digital elevation model extraction results using along-track ASTER and across-track SPOT stereo images. Opt. Eng., 41(9), 2102-2106.

Wolken, G.J. 2006. High-resolution multispectral techniques for mapping former Little Ice Age terrestrial ice cover in the Canadian High Arctic. Remote Sens. Environ., 101(1), 104-114.

Zemp, M., I. Roer, A. Kääb, M. Hoelzle, F. Paul and W. Haeberli. 2008. Global glacier changes: facts and figures. Zürich, World Glacier Monitoring Service; Geneva, United Nations Environment Programme. 